\title{
Executive-Legislative Conflict and Regulation Outcomes: The Case of the U.S. FCC
}

\author{
Jongkon Lee*
}

\begin{abstract}
In the context of regulatory decisions, the political conflict between executive and legislative branches has been significant. The relative ideological stances and power resources of federal agencies and Congress determines regulation outcomes. In particular, when agencies earn sufficient political support from policy stakeholders by relying on procedural justice, they are able to secure the regulatory outcomes they desire without congressional intervention. Because legislators are highly concerned about their reelection prospects, policy stakeholders' political support is an important power resource for agencies. Legislators are likely to embrace regulatory decisions made by agencies supported by policy stakeholders even if they disregard congressional preferences. This article provides evidence for this proposition by reviewing media concentration regulation policies of the U.S. Federal Communications Commission.
\end{abstract}

Keywords: executive-legislative conflict, policy stakeholder support, procedural justice, media concentration regulation, U.S. Federal Communications Commission

\section{INTRODUCTION}

Ideally, important policy values such as efficiency, effectiveness, and equity should guide regulatory decisions. However, in reality, politics instead of policy values determines policies (Freeman, 1985). In particular, ideological conflict among political institutions has tended to determine the direction of regulatory decisions in recent decades. Because of the prevalence of divided government and party polarization in the United States since the 1980s, ideological conflict between the president and Congress has become significant. Except for the 103rd (1993-1995), the 108th and 109th (2003-2006),

\footnotetext{
* Jongkon Lee is an assistant professor of political science and international relations at the Ewha Womans University in South Korea. E-mail: jongkonlee@ewha.ac.kr. This work was supported by an Ewha Womans University 2014 research grant.
}

Manuscript received September 21, 2016; out for review October 13, 2016; review completed December 7, 2016; accepted December 10, 2016.

The Korean Journal of Policy Studies, Vol. 31, No. 3 (2016), pp. 75-99.

(C) 2016 by the GSPA, Seoul National University 
and the 111th (2009-2011) Congresses, the presidential party has not controlled both congressional chambers since 1981 . In addition, significant party polarization between Democratic and Republican parties has intensified the conflict. According to the firstdimension DW-Nominate scores that measure the ideological stances of US legislators, the differences in party ideology medians were 0.547 in the House and 0.558 in the Senate during the 97th Congress (1981-1983). ${ }^{1}$ Scores steeply increased to 1.118 and 0.976 during the 113th Congress (2013-2015). Thus, as figure 1 indicates, the ideological mismatch between the president and Congress has increased dramatically since the 1980s, marking a stark difference from previous periods in which a unified government had been the norm (e.g., the Democratic Party controlled the government from 1932 to 1979, while the Republican Party controlled it between1860 and 1931). Because a president has an incentive to appoint ideologically aligned bureaucrats as agency leaders, ideological conflict between the president and Congress has generally been reproduced

Figure 1. Political Ideologies of U.S. Presidents and Median Legislators

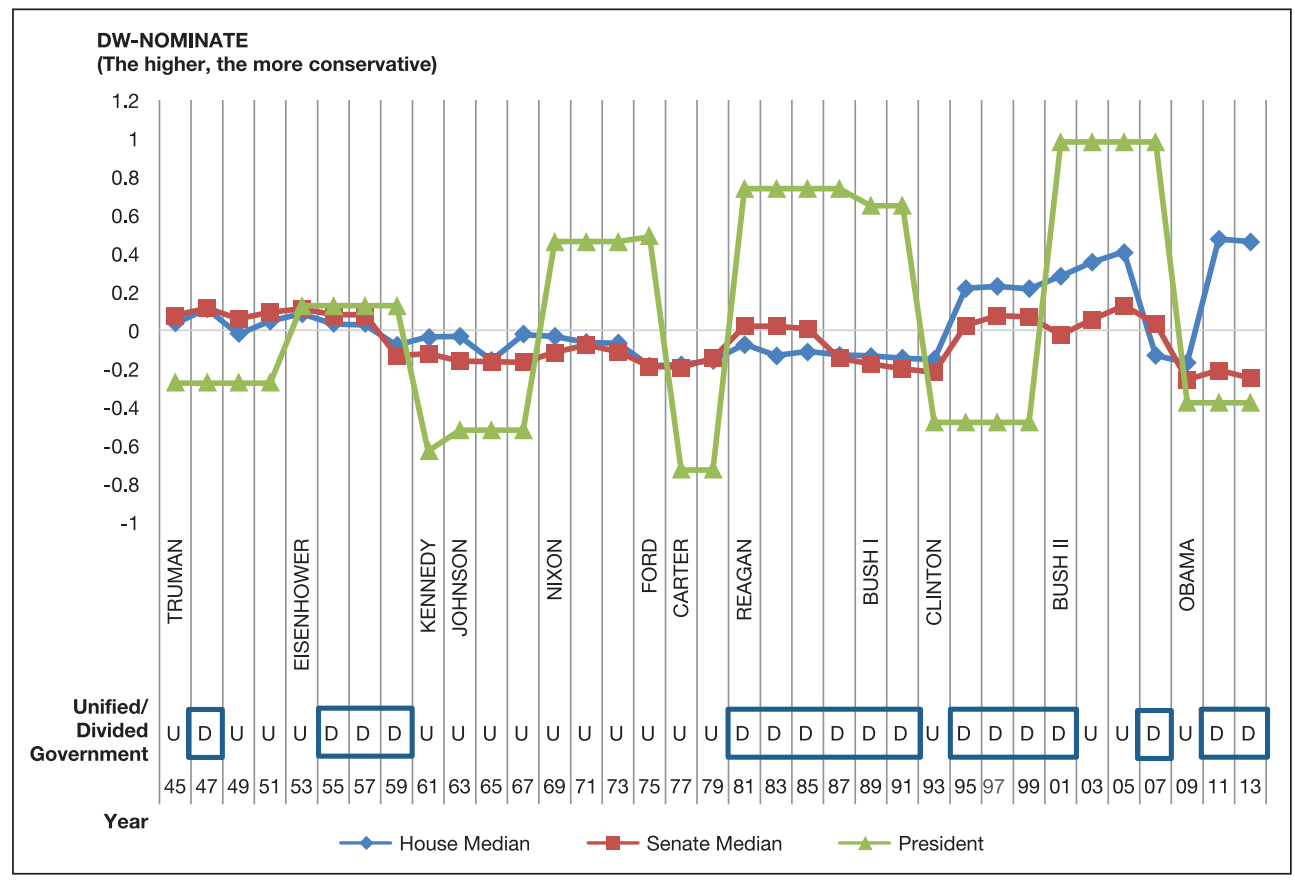

Note: Boxes in the figure indicate divided governments.

1. The DW-Nominate score was calculated based on roll-call votes by Keith T. Poole and Howard Rosenthal. A higher score indicates more conservative ideology. See voteview.com for detailed explanation about DW-Nominate scores. 
in the relations between Congress and federal agencies (Epstein \& O'Halloran, 1999; Moe, 1985). Consequently, the ideological direction of regulatory decisions has been determined by the relative power resources of the two political institutions (Rourke, 1984; Carpenter, 2001, 2010; Epstein \& O’Halloran, 1994; Gailmard, 2002, 2009).

Historically, bureaucratic politics studies have generally maintained that technical expertise allows agencies to acquire significant regulatory authority. Because only a few legislators have the professional knowledge that would enable them to effectively craft regulations, Congress inevitably delegates regulatory authority to agencies, particularly when policy issues are highly complex and agencies have sufficient expertise to deal with the complexity (Epstein \& O'Halloran, 1994; Gailmard, 2002, 2009). In other words, agencies with expertise tend to make regulatory decisions in accordance with their ideologies without congressional intervention (Ogul, 1976; Bawn, 1995; Bertelli, 2012). The effect of agency expertise on regulatory decisions has been discussed from a slightly different perspective in terms of political support from "policy stakeholders," namely, the "people or organizations involved in specific policy issues, who are more directly affected or have a greater degree of interest in the outcome of a particular policy decision" (de Bussy \& Kelly, 2010, p. 297). Policy stakeholders provide agencies that have the expertise to deliver an effective regulatory performance with the political support that can protect the agencies from congressional oversight (Carpenter, 2001, 2010; Foreman, 2002). Even though legislators make regulatory decisions based on their ideologies, they cannot ignore public demands, as doing so could risk their reelection (Mayhew, 1974; Fenno, 1973). Legislators thus tend not to interfere with regulatory decisions made by agencies supported by policy stakeholders (Rourke, 1984; Carpenter, 2001, 2010). Diverse case studies have verified this observation. For example, Corrêa d'Almeida and Klingner (2008) show that the US Federal Emergency Management Agency developed its expertise under the leadership of director James Lee Witt during the 1990s and that this enhanced policy stakeholders' political support, which in turn increased the agency's regulatory authority. Likewise, Wirgau (2013) demonstrates that the U.S. National Endowment for the Arts' professional knowledge contributed to policy stakeholder support and its regulatory autonomy during the 1970s and 1980s.

However, technical expertise is not the only factor that plays a role in policy stakeholders' political support. Their political support can also be enhanced if conflicts that arise among them are mitigated by appropriate administrative procedures (Brown, Cobb, \& Lusch, 2006; Lee, 2016). In the United States, the number of policy stakeholders has increased steeply, and fierce competition among these diverse policy stakeholders had led to serious administrative delays and interruptions in the implementation of regulations (Lee, 2013; Wright, 1996; Holyoke, 2011), making conflict resolution a 
priority for federal agencies (Lan, 1997; Bingham, Nabatchi, \& O'Leary, 2005). As an effective method to resolve such problems, procedural justice, or "the perceived fairness or equity of the procedures used in making decisions," has been highlighted (Lemons \& Jones, 2001, p. 270). Because procedural justice promotes conflict resolution (Lind \& Tyler, 1988; Thibaut \& Walker, 1975; Tyler \& Blader, 2000; Jeon \& Robertson, 2013) and leads to shaping long-term agreements (Pruitt, Peirce, McGillicuddy, Welton, \& Castrianno, 1993), agencies that rely on procedural justice can manage administrative delays and interruptions in the implementation of regulations easily, thereby promoting effective administration and securing significant policy stakeholders support.

Nevertheless, this proposition has not been fully examined by traditional bureaucratic politics studies. Although some studies have discussed the political support procedural justice inspires theoretically (e.g., Carpenter \& Krause, 2012), there have been few studies that address the topic drawing on empirical cases. This article attempts to fill that vacuum by examining the relationship between policy stakeholder support and regulation outcomes in terms of executive-legislative conflict, using media concentration regulation cases of the US Federal Communications Commission (FCC). Even though expertise is an important factor in establishing agency regulatory authority, political support derived from procedural justice has become relatively more important. In particular, when the interaction between policy stakeholders becomes fraught, agencies should follow the precepts of procedural justice in making regulatory decisions.

\section{OVERVIEW OF THE FCC'S POWER RESOURCES AND POLICY STAKEHOLDER SUPPORT}

The case of FCC is useful in examining the relative importance of procedural justice for policy stakeholders, especially when there is a serious ideological conflict between Congress and a federal agency. Even though the FCC is an independent agency, and the service terms of FCC commissioners are fixed, the agency's ideological stance has generally reflected that of the president. Because the agency deals with politically controversial issues, including media ownership and price regulations, US presidents have made significant efforts to appoint ideologically similar bureaucrats as the chairmen of the agency. For example, Mark S. Fowler, who was appointed by President Ronald Reagan, sought to realize Reagan's policy ideas regarding the deregulation of media ownership. Likewise, Reed E. Hundt, the chairman of FCC during the Clinton administration, was a close friend of Vice President Al Gore, and they shared a similar ideology. In addition, the FCC's policy area is highly complex, and technical expertise has long been a major power resource for the agency in making regulatory decisions (Winseck, 
2008; Llorens, 2010; Gormley, 1986) and so provides a good rest case for the proposition that policy stakeholder support based on procedural justice is more important than technical expertise even for agencies whose policy issues are very complex.

The FCC has demonstrated remarkable technical expertise in regulating media ownership and fair competition. For example, the number of high-ranking (i.e., high general schedule [GS]) public officials who tend to have professional knowledge has gradually increased, despite the temporary downturn in the mid-1980s (see figure 2). Because professional employees tend to occupy high GS levels, this measure can also measure agency expertise (Huber \& Shipan, 2002). The average GS level of FCC was always been higher than that of all other US federal agencies. The average GS levels of FCC and all US federal agencies, for example, were 9.45 and 8.16 in 1980, and 12.00 and 9.66 in 2000.

Figure 2. The FCC's Technical Expertise

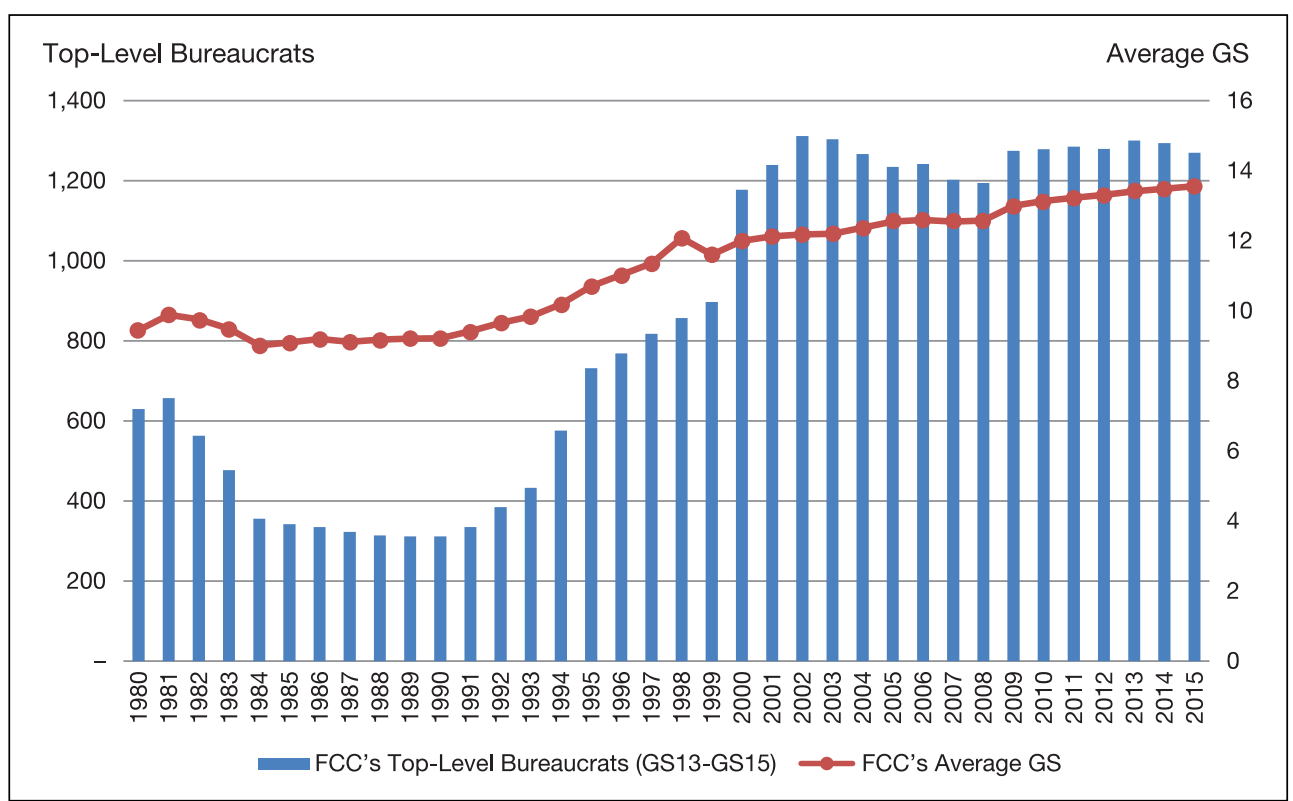

Based on its administrative experiences and professional knowledge, the agency could have continued to reply on its high technical expertise to earn policy stakeholder support and thereby maintain its autonomy from elected officials (Shapiro \& Glicksman, 1988; Zarkin, 2010; Ferejohn \& Shipan, 1989). But US agencies in general have also had to allow policy stakeholders to participate in policy-making processes to secure their support (Oh \& Park, 2013). As the number of policy stakeholders concerned with 
media-related issues has steeply grown in recent decades, the ideological stances of policy stakeholders have also become more visible, and they have recruited policy experts to bolster their policy views (Andres, 2009). ${ }^{2}$ In this way, procedural justice, which calls on an agency to justify its decisions to policy stakeholders, instead of technical expertise has become more important in increasing policy stakeholder support. However, compared with technical expertise, the FCC has made relatively less effort to implement procedural justice. Figure 3 shows that the numbers of advisory committee meetings and their participants have been limited. Because the advisory committee is one of the most important administrative tools by which policy stakeholders in the United States can make their views heard and participate in the regulatory decisionmaking process, the low number of such meetings at the FCC indicates its minimal reliance on procedural justice, in the mid-1980s and the early 1990s. ${ }^{3}$ Only after the mid-1990s did the agency invest more resources in advisory committees, returning to the level of the 1970s.

Consequently, there have been fluctuations in policy stakeholder support for the FCC and subsequent congressional intervention. Figure 4 shows the frequency of Court of Appeals lawsuits against FCC and congressional hearings/the Government Accountability Office (GAO) reports regarding the FCC's administration. To limit possible biases that might arise from regulation size, the numbers of lawsuits, hearings, and GAO reports were divided by the number of the FCC-related Code of Federal Regulations (CFR) pages. In the 1990s and the 2000s, despite the agency's high level of technical expertise (figure 2), because of the limited participation of policy stakeholders (figure 3), many lawsuits were brought against the agency, which indicates a lack of policy stakeholder support (figure 4). Congressional oversight of the FCC has varied in accordance with the frequency of suits brought, and so the number of GAO reports on and congressional hearings about the FCC increased during the mid-1980s. The trend reversed only after the mid-1990s, as FCC began investing again in the participation of policy stakeholders and thus in procedural justice practices; at this point, partly increased policy stakeholder support for the FCC contributed to decreasing

2. According to the Encyclopedia of Associations, there were about 600 or 700 media and telecommunication interest groups in the 1970s in the United States. The number increased to about 1,168 in 1987 . Since that time, the number remained constant at around 1150.

3. In advisory committees, policy stakeholders adjust their opinions, invent new policy alternatives, and reach compromises through due process (Applegate, 1998; Gormley \& Balla, 2004; Landre \& Knuth, 1993; Balla, 2004; Balla \& Wright, 2003). Many studies have argued that advisory committees can promote policy stakeholders' participation through transparent meetings, thereby increasing procedural justice (Beierle \& Long, 1999; Bingham, 2010). 
Figure 3. The FCC's Civic Participation Effort

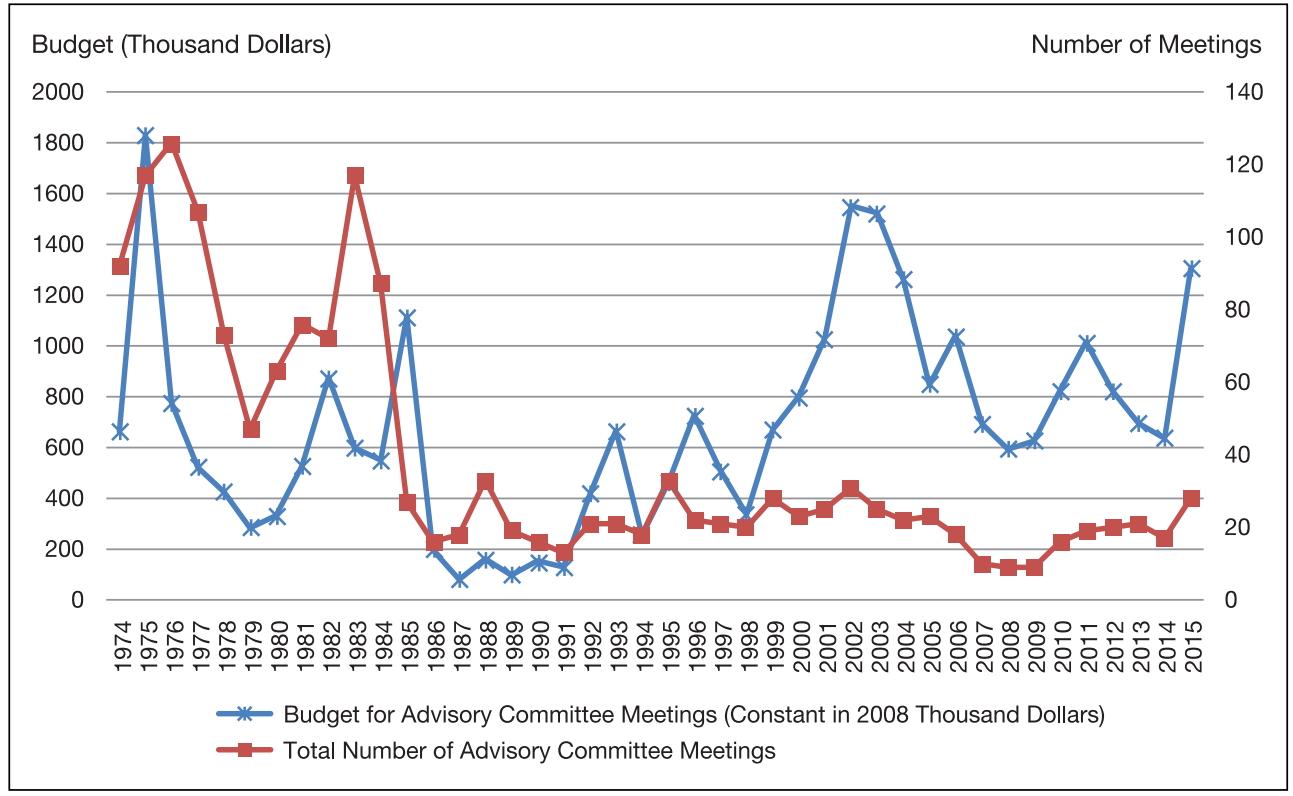

Figure 4. Constituent Complaints and Congressional Oversight on the FCC

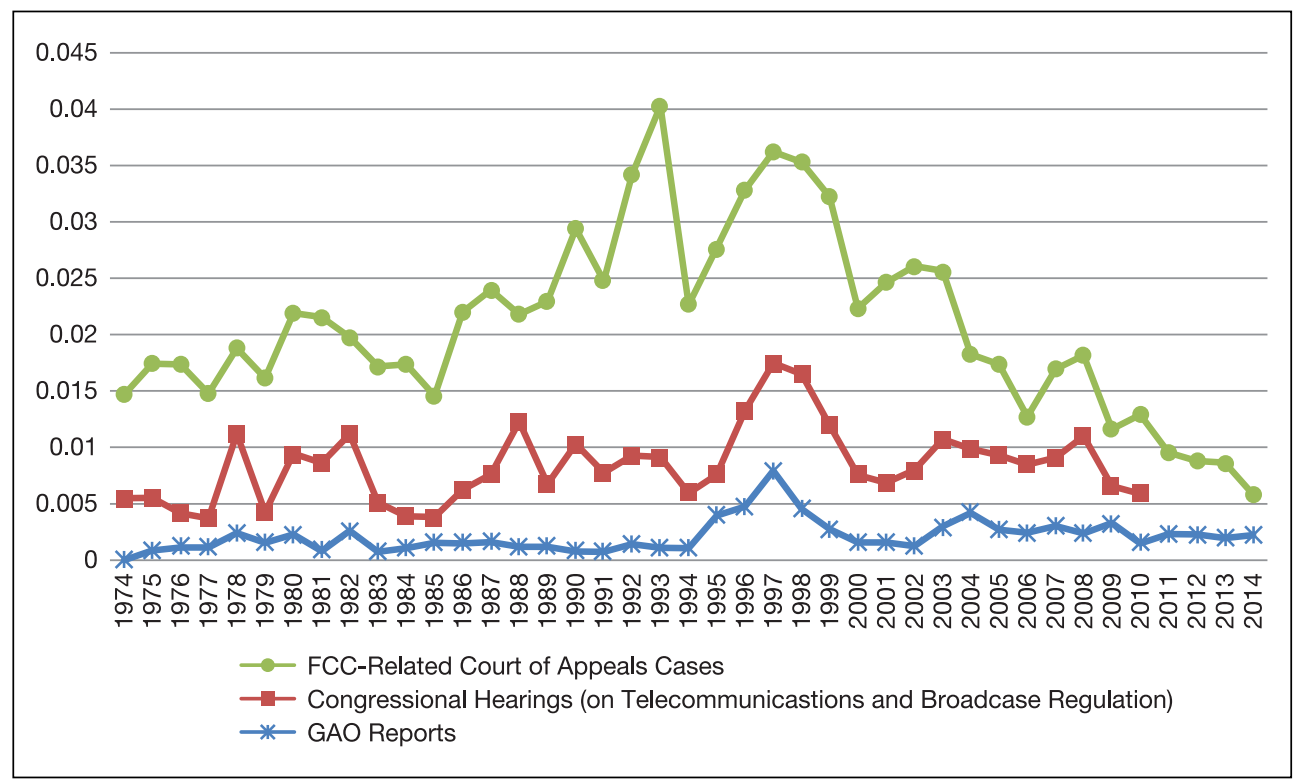

Note: The numbers of lawsuits, hearings, and GAO reports were divided by the FCC-related CFR pages that generally indicate agency regulation size. 
congressional oversight. Even though the FCC's stakeholder support was still not very high even in the 2000s and the 2010s, it clearly contributed to decreasing congressional oversight during the time.

Because media concentration regulation that is related to media ownership and fair market competition has been one of the most complex and politically controversial issues for the FCC (Winseck, 2008; Llorens, 2010; Gormley, 1986), I briefly review the policy history of the FCC's media concentration regulation here. In addition, I consider the relationships among the FCC's policy stakeholder support, congressional oversight, and regulation outcomes in detail.

\section{CASE STUDY: THE FCC'S MEDIA CONCENTRATION REGULATION}

\section{Mark S. Fowler, the Democratic Congress, and the FCC's Deregulation (1981-mid-1980s)}

When President Reagan was inaugurated in 1981, he began deregulating various sectors. Media ownership regulation was one of his targets. The president nominated Mark S. Fowler to lead the FCC in May 1981. Immediately after his appointment was confirmed by the Senate, Fowler let his support for deregulation be known. In a meeting of the International Radio and Television Society in September 1981, he said, "I believe in a marketplace approach to broadcast regulation" (Fowler, 1982, p. 52). To accomplish his goal, Fowler took an uncompromising approach to deregulating media-related policies.

During this time, multiple ownership regulations emerged as the most salient issue. For decades, the FCC had maintained the 7-7-7 rule that limited single company's ownership within seven AM radio stations, seven FM stations, and seven TV stations. On July 26, 1984, FCC voted to replace the long-standing 7-7-7 rule with a 12-12-12 one. In addition, the FCC proposed eliminating all ownership restrictions by 1990. This proposal was highly controversial. Conflict among dominant networks (e.g., $\mathrm{ABC}, \mathrm{NBC}, \mathrm{CBS}$ ) and the proregulation coalitions formed by small television stations (e.g., Westinghouse, Capital Cities, Metromedia), consumer groups (e.g., the Telecommunications Research and Action Center), and trade guilds (e.g., Screen Actors, Directors, Producers, and Writers) was inevitable. Whereas small broadcasters such as the Motion Picture Association of America and National Association of Black Owned Broadcasters criticized the FCC's proposal, big commercial networks applauded it (Shooshan \& Krasnow, 1986). Responding to the controversy, both Democrats and 
moderate Republicans in Congress criticized the FCC's deregulation policy. For example, Sen. Pete Wilson (R-CA) attached a rider to the Supplemental Appropriations Bill that prohibited the FCC from changing its ownership rules until April 1, 1985, or 60 days after the FCC's reconsideration of the new rule (Federal Communications Commission Authorization Act of 1983, P.L. 98-214). Likewise, in September 1984, Sen. Orrin G. Hatch (R-UT) criticized the new rule by saying "I do not believe the commission has established an overwhelming case for the 12-12-12 rule" (Associated Press, 1984). This congressional opposition, however, was not very effective.

Despite the opposition of small broadcasters, the FCC's 12-12-12 rule was highly applauded by dominant media networks. For example, Bernard Mann, president of the National Broadcasters Association, said, "We are glad to see the commission move toward changes in the rule in light of the broadcast industry's evolution and growing diversity in recent years" (Jones, 1984). Many legislators were compelled to show political support for the FCC. Sen. Bob Packwood (R-OR), who was the chairman of the Senate Commerce Committee at the time, said that the 12-12-12 rule was "just great," adding "I am confident that existing antitrust laws will serve the purpose if any problems arise" (Jones, 1984). Likewise, Rep. Timothy E. Wirth (D-CO), the chairman of the Energy and Commerce Subcommittee on Telecommunications, Consumer Protection, and Finance, who already strongly opposed to 12-12-12 rule, offered guarded support for it after a provision for preventing monopoly was attached to it (New York Times, 1984). In addition, the agency had held many advisory committee meetings centered on media ownership issues, including the 12-12-12 rule, thereby addressing the complaints from proregulation groups. Thanks to the FCC's resources, the core of the 12-12-12 rule remained intact, and the FCC's rule was implemented without significant congressional intervention. Congress did enact a six-month moratorium on the rule by appealing to the Second Supplemental Appropriations Act (P.L. 98-396, §304), and the FCC ended up partly revising the 12-12-12 rule by including a provision that prohibited ownership of a group of stations that would reach $25 \%$ of the national audience. Nevertheless, deregulation succeeded against the Democratic Congress; the ownership cap increased from 7 to 12. In sum, in the early 1980s, the FCC was able with the political support of policy stakeholders to prevent congressional intervention and enact a deregulatory rule in line with its policy preferences.

\section{The Democratic Congress and the Enactment of the Cable Act of 1992 (Mid-1980s-1992)}

Despite the FCC's successes, however, Fowler came to believe that advisory meetings with policy stakeholders were unnecessary and even harmful in timely policy 
implementation. Even though he deregulated media ownership by legislating the 12-1212 rule, it took several years for FCC to enact the rule, owing to the public participation of small broadcasters, who delayed prompt enactment of it. Thus, Fowler decided to minimize policy stakeholders' participation opportunities, damaging procedural justice. For example, whereas there had been 76 advisory committee meetings in 1981, there were only 18 meetings in 1987. This decision negatively affected the FCC's policy stakeholder support, because it prevented policy stakeholders from delivering their policy demands to the agency. Consequently, it became harder for FCC to realize its policy preferences in the late 1980s.

During this time, the most important FCC policy issue was cable regulation. In January 1983, Sen. Barry Goldwater (R-AZ) introduced a cable-related bill (S. 66, the Cable Franchise Policy and Communications Act of 1984) that provided FCC with significant policy authority. Despite some opposition from Democratic legislators, Congress passed the Cable Communications Policy Act of 1984, which was then signed by President Reagan on October 30, 1984 (P.L. 98-549). The legislation transformed the policy environment of cable television regulation dramatically. Because the law allowed franchising authorities to regulate basic cable rates when "effective competition" was absent, the FCC's decision on the effective competition standard was very important. In April 1985, the agency released a rule that required at least three unduplicated broadcast signals to be present in a market to satisfy "effective competition." This rule was essentially deregulatory. Because almost all the cable systems already met the standard, they were exempted from local rate controls; they took advantage of the FCC's rule and dramatically increased their rates in the mid-1980s.

The policy environment surrounding the effective competition rule was totally different from that of the 12-12-12 rule in 1984. As figure 3 indicates, the FCC closed down communication channels, and there was no chance for proregulation groups to deliver their political demands to FCC. Thus, proregulation groups such as the National League of Cities and U.S. Conference of Mayors scrambled to Congress. These municipality groups that were not able to regulate the cable industry (because of the FCC rule) prompted proregulation legislators to take action against the rule. Consequently, the Senate Antitrust Subcommittee opened a congressional hearing on the rule in March 1988 and issued a warning about cable rate hikes. In addition, Rep. Edward J. Markey (D-MA), the chairman of the House Telecommunications Subcommittee, asked the GAO to conduct a survey of cable rates. Given this congressional intervention, not only proregulation groups but also antiregulation groups such as the National Cable Television Association (NCTA) began to feel disappointed with the FCC's administration. They believed that the FCC inappropriately appealed to proregulation groups and that that prompted the intervention of the Democratic Congress. Both 
proregulation and antiregulation groups gradually stopped participating in the FCC's policy-making processes. Whereas more than 600 participants annually attended the advisory committee meetings held by FCC in the early 1980s, only about 100 participants remained in the meetings during the late 1980s (e.g., 105 members in 1989). Likewise, the number of lawsuits against the agency also increased; there were only 23 Court of Appeals cases against FCC in 1983, but in 1991, there were 50.

The GAO report that Rep. Markey had requested was released on August 3, 1989. The report said that basic cable rates had risen about $29 \%$ in the first two years after the implementation of the FCC's rule and concluded that the cable industry was a monopoly. Responding to the report, more than a dozen bill intended to intensify cable regulation were introduced in the 101st Congress. Even though these bills were gridlocked by the veto threat of President George H. W. Bush, they nevertheless exposed the FCC. Newly appointed FCC chairman Alfred C. Sikes (1989-1993) felt that it was necessary to increase policy stakeholder support in order to avoid future congressional attacks. Sikes arranged several public hearings designed to mediate conflicts among policy stakeholders and thereby enhance procedural justice. For example, the FCC held three special hearings outside of Washington, DC, in Los Angeles, Orlando, and St. Louis, to discuss competition in the cable television industry in February and March 1990. Then, based on the hearings, the agency approved an effective competition rule on December 13, 1990, that increased the number of unduplicated signals in a local market from three to six.

This new rule, however, was not enough for the FCC to quickly recover policy stakeholder support. The agency failed to persuade proregulation groups that a six-signal standard was sufficient to promote multichannel competition. Many proregulation groups argued that further regulation was necessary to guarantee effective competition in cable markets, and Democratic legislators introduced several bills that included regulatory provisions. And then on October 5, 1992, the Cable Television Consumer Protection and Competition Act of 1992 (hereafter, the Cable Act of 1992), which mandated that the FCC establish a series of tiers for cable pricing and to strengthen cable regulation was enacted, overriding a presidential veto of George H. W. Bush (P.L. 102-385).

\section{Reed E. Hundt and the Enactment of the Telecommunications Act of 1996 (the mid-1990s)}

When Reed E. Hundt (1993-1997) arrived at the FCC in 1993 as the new chairman, the cable rate problem rather than media ownership was the most urgent issue facing the agency. The Cable Act of 1992 required the FCC to revise cable rate rules within 180 days. Due to the expected regulation change, consumer groups and cable industry 
representatives lobbied the agency. Congress too had been paying a lot of attention to the cable issue, even though a unified Democratic government had been temporarily established (January 1993-January 1995). According to Hundt's autobiography, on his first day as the commission chairman, there "were letters from several hundred Congressmen and Senators complaining that the Commission had blundered ... in its rules implementing the 1992 Cable Act" (Hundt, 2000, pp. 19-20). To deal with this issue, he put together a new economic team that included chief economist Michael Katz (an economics professor at the University of California at Berkeley) whose brief was to develop a new method for computing appropriate cable rates, and he also established the Cable Services Bureau.

The revised economic analyses indicated to the FCC that $31 \%$ of subscribers had been overcharged, and so the agency concluded that the introduction of competitive prices would lighten customers' cable bill burden. In addition, FCC ordered a 7\% cut in expanded basic cable service rates on February 22, 1994, in a three to zero vote. ${ }^{4}$ However, this decision was made without the sufficient participation of policy stakeholders, thereby provoking complaints. Steve Effros, the president of the Cable Telecommunications Association, criticized the FCC's decision, saying that "designing its regulations based on what looks good in a headline, rather than what makes real sense" (Farhi, 1994). The NCTA proclaimed that the regulation would "drastically reduce the industry's revenues and that cannot help but reduce our options when it comes to introducing new programming, new services and new technologies" (Sugawara, 1994). Hundt took these criticisms, acknowledging that both technical expertise and procedural justice were highly important in promoting policy stakeholder support: power, he notes in his autobiography, "comes from message coupled with audience." (Hundt, 2000, p. 35). He subsequently held several public meetings with policy stakeholders, including cable executives, in the months after the FCC's new rules were established. Based on what learned at these meetings, he attempted to change the cable rate rules to resolve policy stakeholders' complaints. In November 1994 , he eased the rules and allowed local cable companies to charge more $(\$ 1.50$ more per month) if they added six new channels to their basic programs. As a result, the policy stakeholders became more supportive, compared with the previous period.

The FCC continued to invest in both technical expertise and procedural justice, thereby gradually accumulating policy stakeholder support. The FCC's successful administration in educational television especially contributed to policy stakeholder support. Reed Hundt, who had been an educator before taking the chairman's seat,

4. The FCC had already ordered a 10\% cut in April 1993 under acting chairman James H. Quello. Thus, the new rules imposed an overall 17\% rate reduction on the cable industry. 
emphasized educational television and wanted to mandate that broadcasters carry a certain level of educational programming-so-called kidvid. To implement this policy, he did not adopt a coercive approach but sought instead to persuade policy stakeholders. Hundt held a number of public meetings to mediate between educational groups (e.g., Center for Media Education, Action for Children's Television (ACT)) and commercial networks (e.g., Fox Television, CBS, NBC). In addition, he had personal contacts with influential actors, including Peggy Charren, the head of the ACT, and network moguls such as Rupert Murdoch (Fox Television), Larry Tisch (CBS), and Bob Wright (NBC). Finally, the FCC reached an agreement for a three-hour quota from CBS in exchange for approval of its merger with Westinghouse Electric Corp. Fox and NBC also subsequently accepted the regulation. This agreement was reached through the participation of diverse media-related participants, and the success of the administrative process enhanced policy stakeholder support for the FCC.

When Republicans took control of both houses of Congress in January 1995 and announced their "Contract with America," executive-legislative conflict escalated. During this time, Democratic president Bill Clinton and vice president Al Gore introduced the idea of new public management and emphasized market competition in public spheres. Reed Hundt also agreed with the deregulatory plans of the Democratic president: "In some respects," he observed, "our agenda could benefit from the Republican Revolution" (2000, p. 98). However, the Republican Congress sought to go beyond deregulation and tried to "repeal" the agency. Rep. Jack M. Fields (R-TX), chairman of the House Commerce Subcommittee on Telecommunications, and House Speaker Newt Gingrich (R-GA) led the effort to emasculate FCC. Rep. Fields said, "There's a strong feeling among those in the industry and many of us in Congress that the FCC is an impediment to new technologies coming forward" (Mills, 1995).

However, public opinion indicated that the agency should be given more regulatory authority with which to effect deregulation. Given this political atmosphere, it was nearly impossible for the Republican Congress to repeal the agency. Instead, in a bipartisan vote, Congress passed the Telecommunications Act of 1996 (P.L. 104-104). The bill approved the deregulation of media markets. In addition, the bill enhanced the regulatory authority of the FCC by providing it with significant discretion. In the signing statement of the bill, President Clinton praised the law by saying that "this landmark legislation fulfills my Administration's promise to reform our telecommunications laws in a manner that leads to competition and private investment ... and provides for flexible government regulation." Hundt later remarked that the "Telecommunications Act of 1996 made me ... one of the most powerful persons in the communications revolution" (2000, p. 148).

Reed Hundt's successor, William Kennard (1997-2001), also strategically invested 
more money in public participation to increase policy stakeholder support. The cost for the advisory committees and the number of agency meetings with policy stakeholders steeply increased during Kennard's tenure. Over the course of the 1990s, the number of public meetings (that were announced in the Federal Register during a year) went from less than 200 to about 800, and the budget for advisory committees increased from about \$0.1 million (in constant FY 2008 dollars) to more than \$1 million.

\section{Michael K. Powell's Deregulatory FCC and the Democratic Congress (2001-2005)}

During Michael K. Powell's chairmanship of the FCC in the early 2000s, media ownership issues reemerged. ${ }^{5}$ While the Telecommunications Act of 1996 had resolved certain long-standing controversies surrounding cable television regulation, its provision for biennial reviews over broadcast ownership rules along with a February 2002 decision by the US Court of Appeals for the D.C. Circuit to the effect that the $35 \%$ ownership cap for television stations was "arbitrary and capricious" gave the FCC the opportunity to revisit ownership regulation rules. ${ }^{6}$ In September 2002, the agency decided to review six media ownership rules by a unanimous four to zero vote. ${ }^{7}$

Powell preferred prompt deregulatory action to burdensome administrative procedures. He believed that the agency could acquire sufficient policy-stakeholder support by promoting technical expertise. In a public hearing on media ownership, he said, "The FCC staff kicked off that effort by conducting a dozen studies on the workings of the media.... This rulemaking will be driven by evidence, not intuition or personal preference" (Federal Communications Commission, 2003). The FCC put a lot of emphasis on the diversity index (DI), which quantified the number of media outlets (e.g., television, radio, newspaper, and the internet) and media companies. Drawing on this index and other data, the FCC claimed that deregulation in media ownership was not undermining either local markets or competition.

However, Powell largely neglected procedural justice, which instigated complaints

5. Powell was a staunch advocate of deregulation of the mass media market in general and of television ownership deregulation in particular. "Monopoly," he observed, "is not illegal by itself in the United States" (McChesney, 2004a, p. 227).

6. The case was Fox Television v. FCC, 280 F.3d 1027 (D.C. Cir. 2002). This decision was supported by Sinclair Broadcast Group, Inc. v. FCC, 284 F.3d 148 (D.C. Cir. 2002).

7. Gloria Tristani, an FCC commissioner, resigned on September 7, 2001. Before December 3, 2002, when Jonathan S. Adelstein was appointed as a new commissioner, there had been only four FCC commissioners. On October 28, 2002, the FCC published a notice of proposed rule making on ownership relaxation in the Federal Register (67 Fed. Reg. 65,751). 
from policy stakeholders. As Michael J. Copps-one of the FCC's commissionerssaid regarding the rulemaking, "The Commission faces a far more informed and involved citizenry. The obscurity of the issue that many have relied upon in the past... is gone forever" (McChesney, 2004b, p. 285). Policy stakeholders had themselves accumulated professional knowledge, and so the FCC could not count on earning their support solely by referencing unproven scientific studies. Citizen groups such as the Consumer Union and the Consumer Federation of America published their own scientific reports to refute the results of the FCC's studies. They hired media specialists and asserted that the FCC's studies were biased because they neglected critical factors in estimating media ownership (e.g., the size and diversity of population served by the media) and that the FCC's deregulatory rules would result in concentrated media markets (Associated Press, 2002). Several proregulation groups such as National Association of Hispanic Journalists, the National Organization for Women, the Center for Digital Democracy, and the American Federation of Labor and Congress of Industrial Organizations had also expressed doubts about the FCC's media ownership deregulation proposals. Some of them sought to refute the FCC's claims by presenting their own scientific research and data and proclaimed that the diversity index exaggerated real markets, neglected to take into account certain points of view, and used biased examples (Freedman, 2008).

These hostile responses from policy stakeholders led several legislators to criticize the FCC's policies. Sen. Byron L. Dorgan (D-ND) said, "We are heading in exactly the wrong direction... You should have your foot on the brake, not your hand on the throttle," while Sen. Ronald R. Wyden (D-OR) warned that the FCC's policies could result in the media landscape being dominated even by just company (Stern, 2003). Many Democratic legislators demanded that the FCC delay its expected vote on the media ownership deregulation rule. Several Republicans also expressed concerns about the FCC's desire to further deregulate media ownership. Sen. Olympia J. Snowe (R-ME) said that the FCC should "justify how any changes in media rules will promote the goals of diversity, competition and localism," and Sen. Trent Lott (R-MS) noted that "the media ownership rules are working well. We should leave them as they are" (Ahrens, 2003c). Despite these political pressures, however, the FCC decided to push forward, and on June 2, 2003, it voted to relax important media ownership regulations including television ownership caps and cross-ownership restrictions. ${ }^{8}$

The new regulations permitted a broadcast network to increase its market coverage to $45 \%$ percent (under the old rule, it was $35 \%$ ), and the bans on multiple ownership

8. This rule was released on July 2, 2003 and published in Federal Register on August 5, 2003 (68 Fed. Reg. 46, 286). 
of newspapers and television (and television and radio) that had been in place since 1975 were eliminated. Immediately after the FCC's vote, policy stakeholders voiced their objections through judicial challenges and lobbies. The lack of policy stakeholder support led to congressional intervention; congressional black, Hispanic and Asian Pacific American caucuses argued that the rules would result in the shutdown of minority broadcasting ownership. ${ }^{9}$ Many other legislators such as Sen. John F. Kerry (D-MA), Sen. Daniel R. Graham (D-FL), and Rep. Nancy Pelosi (D-CA) publicly declared their opposition to the new rules. Sen. Ernest Hollings (D-SC) expressed doubt about the FCC's expertise, asking, "Where in the world do you find the grounds for 45 percent?" (Ahrens, 2003b). Certain Republican legislators who had urged the FCC to not relax the rules continued to criticize them. Sen. Olympia Snowe, for example, said that the rules would "undermine the basic tenets of democracy and objectivity in reporting and may have long-term consequences in terms of public access to information" (Ahrens, 2003a). Legislative attempts to overturn the FCC's rule followed. On July 15, 2003, Sen. Dorgan led a resolution of disapproval on the FCC's ownership rules (S.J.Res. 17) with the support of Sen. Hollings and Sen. Lott, and on July 23, 2003, a bipartisan coalition in the House passed an appropriation bill to prohibit the FCC from using funds to implement its new rules by a 400-21 vote (H.R. 2799, §624). Finally, legislators compromised at a 39\% ownership cap and enacted the Consolidated Appropriations Act of 2004 (P.L. 108-199) that suspended the FCC's ownership rule and instructed the FCC to modify its ownership rules (\$629). This bill was signed into law by President George W. Bush on January 23, 2004.

In sum, although Powell's FCC made efforts to enhance technical expertise through scientific studies, the agency failed to acquire sufficient policy stakeholder support. The complaints of policy stakeholders that resulted from the FCC's ignoring of administrative procedures ultimately prevented the agency from realizing its desired policies.

\section{Kevin J. Martin's Deregulatory FCC and the Democratic Congress (the late 2000s)}

The controversies surrounding media persisted into the mid-2000s. In June 2005, the U.S. Supreme Court declined to hear a case about the constitutionality of the FCC's new ownership rules, forcing the FCC to draft a new rule. Citizen groups such

9. In particular, in Prometheus Radio Project v. FCC (2004), the Prometheus Radio Project argued that the rule violated the Administrative Procedure Act's public notice requirement procedure. 
as Media Access Project (MAP) asserted that ownership restrictions were necessary in order to promote diversity and democratic values. In contrast, media groups said that the old ownership rules were outdated.

It would be nearly impossible for the FCC to change the $39 \%$ media ownership cap that had been the compromise cap agreed to by Congress. Instead, on June 21, 2006, FCC chairman Kevin J. Martin (2005-2009), who had been a commissioner of FCC since 2001 and was promoted to FCC chairman in March 2005, announced that the FCC would amend the cross-ownership rules that Powell had not ended up changing (i.e., restrictions that prevented a company from possessing both a newspaper and a television or radio station in the same city). However, no policy stakeholders supported this idea. Gene Kimmelman, vice president of Consumers Union, said that "if the FCC goes too far down a deregulatory approach to media ownership or related areas, it will face a barrage of criticism from Congress" (Babington, 2007a). On the other side, the president of the Newspaper Association, John F. Sturm, said that Martin's idea was only an insufficient "baby step" (Labaton, 2007). These unfavorable responses from policy stakeholders opened congressional oversight on the agency. In a congressional hearing in January 2007, Sen. Dorgan said that the Democratic majority in the 100th Congress would force the FCC, which had "effectively emasculated any public-interest standards," to "beat a path to Capitol Hill to respond" (Babington, 2007b). On November 8, 2007, Sen. Dorgan introduced a bill (S. 2332) to establish detailed administrative procedures to modify media ownership rules. ${ }^{10}$ In addition, one day before the FCC's vote, 25 Senators sent a letter to Kevin Martin, saying, "If you proceed to take final action on this rule on December 18 without having given reasonable opportunity for comment on the actual rules and study of the related issues, we will immediately move legislation that will revoke and nullify the proposed rule" (Geewax, 2007).

In this negative political atmosphere, Martin saw the necessity of enhancing policystakeholder support. In his former position as an FCC commissioner, Martin had witnessed the failure of former Chairman Michael Powell. In light of that experience, Martin made efforts to promote public participation after he announced his new media cross-ownership rule. The public notice period that the FCC provided was long, more than 120 days. During this time, the agency received thousands of oral comments and over 166,000 written comments. In addition, the agency held more than six hearings (in Los Angeles, Nashville, Harrisburg, Tampa Bay, Chicago, and Seattle), in which diverse policy stakeholders including broadcasters and corporations participated. The agency also supplemented technical expertise by investing almost $\$ 700,000$ in 10

10. An identical bill was introduced in the House (H.R. 4835) by Rep. Jay R. Inslee (D-WA) on December 18, 2007. 
independent studies on media cross-ownership. These efforts contributed to increasing policy stakeholder support. Even though there was no enthusiastic applause for the rule, both proregulation and antiregulation policy stakeholders tacitly admitted the legitimacy of the FCC's deregulation plan.

As a result, although several legislators including Sen. Lott and Sen. Dorgan asked FCC to delay the vote, the agency was able to push ahead, and on December 18, 2007, by a vote of three to two, it eased cross-ownership regulation. It published its crossownership rule in the Federal Register on February 21, 2008. ${ }^{11}$ Even though the rule did not reflect congressional preferences, the Democratic Congress did not seriously attempt to block the agency. Even though joint resolutions of disapproval to stop FCC from implementing the rule (e.g., H.J.Res. 79 and S.J.Res. 28) and some legislative bills that would negate the rule (e.g., S. 2332 and H.R. 4835) were introduced, they were not enacted. In sum, the FCC under Kevin Martin that was supported by policy stakeholders was able to push through its preferred policy, successfully avoiding the intervention of a regulatory Congress.

\section{The FCC in the 2010s and Policy Stakeholder Support}

Despite a unified Democratic government in Barack Obama's first term (2008-12), executive-legislative conflicts persisted, and certain FCC policy decisions were overturned by Congress owing to a lack of policy stakeholder support. The new FCC chairman, Julius Genachowski, was a Democrat appointed by President Barack Obama, but he favored deregulatory policies. He was a protégé of former FCC chairman Reed Hundt and a senior legal advisor to the former chairman during the mid1990s, and his administrative ideology was similar to that of Hundt. In Prometheus Radio Project v. FCC in July 2011, the US Court of Appeals for the Third Circuit decided that the FCC failed to comply with the notice and comment provisions of the Administrative Procedures Act in enacting the 2008 cross-ownership rule and instructed FCC to better consider how its rules would affect and could promote ownership by women and people of color, which led Genachowski to develop a new proposal to loosen the rule. ${ }^{12}$ FCC spokesman Justin Cole commented in an interview that the FCC's deregulation efforts were intended "to streamline and modernize media ownership rules, including eliminating outdated prohibitions on newspaper-radio and TV-radio

11. In detail, one entity would be permitted to own a newspaper and one broadcast station simultaneously in the 20 largest media markets, under the condition that at least 8 independently owned and operated media voices must remain.

12. The Supreme Court declined to hear the case. 
cross-ownership." The reaction of many policy stakeholders to the FCC's decision was negative.

Nevertheless, FCC cut back on its investment in public participation, thereby decreasing procedural justice and failing to effectively deal with hostile policy stakeholders' responses. Andy Schwartzman, the president of MAP, said in a newspaper interview that if the FCC was "going to keep the same cross-ownership rules that Kevin Martin adopted," then "we would fight it very hard." These complaints provoked the Democratic Congress to intervene. On November 30, 2012, several legislators, including Sen. Bernie Sanders (I-VT) and Sen. Patrick Leahy (D-VT), sent a joint letter to Genachowski, in order to oppose the FCC's proposal to loosen media ownership rules. They said, "We respectfully request that the FCC not proceed with its proposed rule changes without providing a clear, evidence-based response to these concerns, not only because it is required by the Third Circuit's ruling, but also in light of the significant public objection that has accompanied past attempts to change this rule." Owing to this legislative pressure, the FCC delayed a vote on the media ownership rule, and Genachowski resigned in March 2013. In December 2013, Tom Wheeler, who replaced Genachowski, withdrew the proposal to relax the ban media cross-ownership. In sum, in the early 2010s, the FCC did not have enough policy stakeholder support to prevent its proposed regulations from being challenged by Congress.

\section{CONCLUSION}

This article examines that relationship between policy stakeholder support and regulation outcomes in terms of executive-legislative conflict based on a case study of the FCC. In the United States, there are multiple policy-making institutions, including Congress and federal agencies, and their policy ideologies have frequently been different. In the face of the severe ideological polarization of the political parties and the prevalence of a divided government, executive-legislative conflict in particular has become sharper in recent years. Because federal agencies have a normative obligation to propose legislation, their regulatory decisions can be easily overturned by Congress. Thus, it is very hard for agencies to secure their preferred policies without sufficient power resources to deflect congressional intervention. Policy stakeholder support is one of the most important power resources for agencies. The case study of this article shows that the FCC has only been successful in implementing its preferred regulation policies, when it has had sufficient policy-stakeholder support.

There are two factors that determine policy stakeholder support: technical expertise and procedural justice. Even though technical expertise has been highlighted by many 
political science and public administration studies (Eisner \& Meier, 1990; Rourke, 1984; Worsham, Eisner, \& Ringquist, 1997; Meier, 1987; Gailmard \& Patty, 2007; Aghion \& Tirole, 1997), procedural justice has received less attention (Rourke, 1984; Carpenter, 2001, 2010). In the case of the FCC, even though it has almost always demonstrated significant technical expertise (see figure 2), it has frequently failed to prevent congressional intervention. In particular, when the FCC neglected the political demands of policy stakeholders, its proposals tended to be reversed by Congress. Procedural justice has been a prerequisite for FCC to acquire sufficient policy stakeholder support and realize its policy goals.

For example, during the early 2000s, Michael K. Powell emphasized technical expertise, largely ignoring procedural justice. As a result, the FCC's decision to cap media ownership at $45 \%$ was overturned by Congress. In addition, the agency failed to enact a deregulatory cross-ownership rule. In contrast, in the late 2000 s, Kevin J. Martin promoted procedural justice as means of acquiring sufficient policy stakeholder support to enact the cross-ownership rule. Significant interaction with policy stakeholders and frequent public hearings earned the agency the necessary policy stakeholder support and enabled the implementation of the cross-ownership rule. Even though the FCC's rule ran counter to congressional preferences, Congress was not able to challenge a policy that had so much support from policy stakeholders.

In sum, the power resources of agencies is an important factor in determining policy direction, given executive-legislative conflict in the United States. In particular, policy stakeholder support for agencies (regarding technical expertise and procedural justice) has affected the political relationship between the executive and legislative branches and thereby influenced regulation outcomes.

\section{REFERENCES}

Aghion, P., \& Tirole, J. 1997. Formal and real authority in organizations. Journal of Political Economy, 105(1): 1-29.

Ahrens, F. 2003a. FCC eases media ownership rules; party-line vote clears way for more consolidation. Washington Post, June 3, A1.

Ahrens, F. 2003b. Senators attack FCC rules; most on oversight panel sign on to revise changes. Washington Post, June 5, E4.

Ahrens, F. 2003c. Unlikely alliances forged in fight over media rules. Washington Post, May 20, E1.

Andres, G. J. 2009. Lobbying reconsidered: Real politics in America. New York: Pearson Longman. 
Applegate, J. S. 1998. Beyond the usual suspects: The use of citizens advisory boards in environmental decisionmaking. Indiana Law Journal, 73(3): 903-957.

Associated Press. 1984. Senate panel skeptical over new FCC plan. New York Times, September 12. Retrieved on December 22, 2016, from www.nytimes.com/ 1984/09/12/arts/senate-panel-skeptical-over-new-fcc-plan.html.

Associated Press. 2002. Groups say FCC will relax media merger restrictions; move is bad for consumers, they say. St. Louis Post-Dispatch, December 16, A5.

Babington, C. 2007a. Congress nudges an FCC on hold; agency tackles backlog of pending matters after Democrats complain. Washington Post, April 4, D1.

Babington, C. 2007b. FCC to feel unfamiliar heat from Democrats. Washington Post, January 26, A4.

Balla, S. J. 2004. Between commenting and negotiation: The contours of public participation in agency rulemaking. I/S: A Journal of Law and Policy for the Information Society, 1(1): 59-94.

Balla, S. J., \& Wright, J. R. 2003. Consensual rule making and the time it takes to develop rules. In G. A. Krause and K. J. Meier (eds.), Politics, Policy, and Organizations: Frontiers in the Scientific Study of Bureaucracy (pp. 187-206). Ann Arbor: University of Michigan Press.

Bawn, K. 1995. Political control versus expertise: Congressional choices about administrative procedures. American Political Science Review, 89(1): 62-73.

Beierle, T. C., \& Long, R. J. 1999. Chilling collaboration: The federal advisory committee act and stakeholder involvement in environmental decision making. Environmental Law Reporter, 29(7): 10399-10410.

Bertelli, A. 2012. The political economy of public sector governance. New York: Cambridge University Press.

Bingham, L. B. 2010. The next generation of administrative law: Building the legal infrastructure for collaborative governance. Wisconsin Law Review, 2010(2): 297-356.

Bingham, L. B., Nabatchi, T., \& O’Leary, R. 2005. The new governance: Practices and processes for stakeholder and citizen participation in the work of government. Public Administration Review, 65(5): 547-558.

Brown, J. R., Cobb, A. T., \& Lusch, R. F. 2006. The roles played by interorganizational contracts and justice in marketing channel relationships. Journal of Business Research, 59(2): 166-175.

Carpenter, D. P. 2001. The forging of bureaucratic autonomy: Reputations, networks, and policy innovation in executive agencies, 1862-1928. Princeton, NJ: Princeton University Press.

Carpenter, D. P. 2010. Reputation and power: Organizational image and pharmaceutical 
regulation at the FDA. Princeton, NJ: Princeton University Press.

Carpenter, D. P., \& Krause, G. A. 2012. Reputation and public administration. Public Administration Review, 72(1): 26-32.

Corrêa d'Almeida, A., \& Klingner, D. E. 2008. FEMA and the Witt revolution: Testing the hypothesis of "bureaucratic autonomy." Public Organization Review, 8(4): 291-305.

de Bussy, N. M., \& Kelly, L. 2010. Stakeholders, politics and power: Towards an understanding of stakeholder identification and salience in government. Journal of Communication Management, 14(4): 289-305.

Eisner, M. A., \& Meier, K. J. 1990. Presidential control versus bureaucratic power: Explaining the Reagan revolution in antitrust. American Journal of Political Science, 34(1): 269-287.

Epstein, D., \& O'Halloran, S. 1994. Administrative procedures, information, and agency discretion. American Journal of Political Science, 38(3): 697-722.

Epstein, D., \& O’Halloran, S. 1999. Delegating powers: A transaction cost politics approach to policy making under separate powers. New York: Cambridge University Press.

Farhi, P. 1994. FCC to try to cut cable TV rates again. Times Union, January 25, A1.

Fenno, R. F. 1973. Congressmen in committees. Boston: Little, Brown.

Ferejohn, J., \& Shipan, C. R. 1989. Congressional influence on administrative agencies: A case study of telecommunications Study. In L. C. Dodd and B. I. Oppenheimer (eds.), Congress Reconsidered (pp. 393-410). Washington DC: CQ Press.

Foreman, C. H. 2002. The civic sustainability of reform. In D. F. Kettl (ed.), Environmental Governance: A Report on the Next Generation of Environmental Policy (pp. 146-176). Washington DC: Brookings Institution.

Fowler, M. S. 1982. The public's interest. Communications and the Law, 4(1): 51-58.

Freedman, D. 2008. The politics of media policy. Malden, MA: Polity.

Freeman, G. P. 1985. National styles and policy sectors: Explaining structured variation. Journal of Public Policy, 5(4): 467-496.

Gailmard, S. 2002. Expertise, subversion, and bureaucratic discretion. Journal of Law, Economics, and Organization, 18(2): 536-555.

Gailmard, S. 2009. Discretion rather than rules: Choice of instruments to control bureaucratic policy making. Political Analysis, 17(1): 25-44.

Gailmard, S., \& Patty, J. W. 2007. Slackers and zealots: Civil service, policy discretion, and bureaucratic expertise. American Journal of Political Science, 51(4): 873-889.

Geewax, M. 2007. FCC relaxes media rules on ownership. Atlanta Journal-Constitution, December 19, C1. 
Gormley, W. T. 1986. Regulatory issue networks in a federal system. Polity, 18(4): 595-620.

Gormley, W. T., \& Balla, S. J. 2004. Bureaucracy and democracy: Accountability and performance. Washington, DC: CQ Press.

Holyoke, T. T. 2011. Competitive interests: Competition and compromise in American interest group politics. Washington, DC: Georgetown University Press.

Huber, J. D., \& Shipan, C. R. 2002. Deliberate discretion? The institutional foundations of bureaucratic autonomy. New York: Cambridge University Press.

Hundt, R. E. 2000. You say you want a revolution: A story of information age politics. New Haven, CT: Yale University Press.

Jeon, S. H., \& Robertson, P. J. 2013. Should I stay or should I go: The impact of public duty motivation on turnover intentions. Korean Journal of Policy Studies, 28(2): $1-24$.

Jones, A. S. 1984. FCC Raises limit on total stations under one owner. New York Times, July 27, D2.

Labaton, S. 2007. FCC eases media ownership rule. New York Times, December 18. Retrieved on December 22, 2016, from www.nytimes.com/2007/12/18/business/ 18cnd-fcc.html.

Lan, Z. 1997. A conflict resolution approach to public administration. Public Administration Review, 57(1): 27-35.

Landre, B. K., \& Knuth, B. A. 1993. Success of citizen advisory committees in consensus-based water resources planning in the Great Lakes basin. Society and Natural Resources, 6(3): 229-257.

Lee, J. 2013. The administrative broker: Bureaucratic politics in the era of prevalent information. American Review of Public Administration, 43(6): 690-708.

Lee, J. 2016. Designed to succeed: Participatory governance, transaction cost, and policy performance. Korean Journal of Policy Studies, 31(2): 1-22.

Lemons, M. A., \& Jones, C. A. 2001. Procedural justice in promotion decisions: Using perceptions of fairness to build employee commitment. Journal of Managerial Psychology, 16(4): 268-281.

Lind, E. A., \& Tyler, T. R. 1988. The social psychology of procedural justice. New York: Plenum Press.

Llorens, C. 2010. Structural media pluralism/Spanish media concentration policy: A crucial patchwork to understand Spanish media system. International Journal of Communication, 4(1): 844-864.

Mayhew, D. R. 1974. Congress: The electoral connection. New Haven, CT: Yale University Press.

McChesney, R. W. 2004a. Media policy goes to Main Street: The uprising of 2003. 
Communication Review, 7(3): 223-258.

McChesney, R. W. 2004b. The problem of the media: U.S. communication politics in the 21st century. New York: Monthly Review Press.

Meier, K. J. 1987. Politics and the bureaucracy: Policymaking in the fourth branch of government. Monterey, CA: BrookslCole.

Mills, M. 1995. Republicans map out an assault on FCC's powers. Washington Post, April 13, D12.

Moe, T. M. 1985. Control and feedback in economic regulation: The case of the NLRB. American Political Science Review, 79(4): 1094-1116.

New York Times. 1984. Rule eased on owning TV stations. New York Times, December 20. Retreived on December 22, 2016, from www.nytimes.com/1984/12/20/arts/ rule-eased-on-owning-tv-stations.html.

Ogul, M. S. 1976. Congress oversees the bureaucracy: Studies in legislative supervision. Pittsburgh, PA: University of Pittsburgh Press.

Oh, Y. M., \& Park, J. 2013. The effect of Political institutions on the use of citizen participation programs. Korean Journal of Policy Studies, 28(2): 25-48.

Pruitt, D. G., Peirce, R. S., McGillicuddy, N. B., Welton, G. L., \& Castrianno, L. M. 1993. Long-term success in mediation. Law and Human Behavior, 17(3): 313-330.

Rourke, F. E. 1984. Bureaucracy, politics, and public policy. 3rd ed. Boston: Little, Brown.

Shapiro, S. A., \& Glicksman, R. L. 1988. Congress, the Supreme Court, and the quiet revolution in administrative law. Duke Law Journal, 1988(5): 819-878.

Shooshan, H. M., III, \& Krasnow, E. G. 1986. Congress and the Federal Communications Commission: The continuing contest for power. Hastings Journal of Communications and Entertainment Law, 9(1): 619-633.

Stern, C. 2003. Deregulation plans assailed; senators question agenda of FCC's chairman. Washington Post, January 15, E5.

Sugawara, S. 1994. Rules issued for cutting cable rates; industry may take FCC to court. Washington Post, March 31, d11.

Thibaut, J. W., \& Walker, L. 1975. Procedural justice: A psychological analysis. New York: Lawrence Erlbaum Associates.

Tyler, T. R., \& Blader, S. L. 2000. Cooperation in groups: Procedural justice, social identity, and behavioral engagement. Ann Arbor, MI: Braun-Brumfield.

Winseck, D. 2008. The state of media ownership and media markets: Competition or concentration and why should we care? Sociology Compass, 2(1): 34-47.

Wirgau, J. S. 2013. Quality and access: Bureaucratic autonomy and the role of storylines at the National Endowment for the Arts. Administration and Society, 45(3): 296-325. 
Worsham, J., Eisner, M. A., \& Ringquist, E. J. 1997. Assessing the assumptions: A critical analysis of agency theory. Administration Society, 28(4): 419-440.

Wright, J. R. 1996. Interest groups and Congress: Lobbying, contributions, and influence. Boston: Allyn and Bacon.

Zarkin, M. 2010. The FCC and the politics of cable TV regulation, 1952-1980. New York: Cambria Press. 